\title{
RANCANG BANGUN CHATBOT PEMBELAJARAN JAVA PADA GOOGLE CLASSROOM DAN FACEBOOK MESSENGER
}

\author{
Mokhamad Hadi Wijaya ${ }^{1}$, Moechammad Sarosa ${ }^{2}$, Herman Tolle ${ }^{3}$ \\ ${ }^{1}$ Fakultas Teknik Elektro Universitas Brawijaya Malang \\ ${ }^{2}$ Politeknik Negeri Malang \\ ${ }^{3}$ Fakultas Ilmu Komputer Universitas Brawijaya Malang \\ Email: ${ }^{1}$ hadi@smktelkom-mlg.sch.id, ${ }^{2}$ msarosa@polinema.ac.id, ${ }^{3}$ emang@ub.ac.id
}

(Naskah masuk: 31 Mei 2018, diterima untuk diterbitkan: 7 Agustus 2018)

\begin{abstract}
Abstrak
Aplikasi kelas online telah diterapkan di SMK Telkom Malang menggunakan platform Google Classroom pada mata pelajaran Pemrograman Berorientasi Objek (PBO). Google Classroom pada mata pelajaran PBO ditambahkan materi chatbot pembelajaran Java dari Oracle Academy Java Foundation menggunakan platform Facebook Messenger. Kedua media pembelajaran tersebut dapat membantu Guru dalam menyediakan materi kepada siswa diantaranya adalah materi dasar pemrograman Java dan penyajian item soal kuis. Pada model kuis yang disajikan chatbot ini, antar siswa mendapat respon penyajian item soal yang berbeda dalam pengerjaan kuis tentang materi yang ditampilkan sesuai dengan score tingkat kesulitan soal yang dikerjakan oleh siswa dengan metode Organizing Exercise Items. Pada hasil pengujian, chatbot diterapkan pada pembelajaran 3 kelas dan dapat menghasilan nilai hasil final ujian lebih tinggi dengan selisih rata-rata 0.60 poin dari kelompok pembelajaran konvensional. Pada hasil belajar juga terdapat kenaikan nilai pada post test sebesar 0,39 poin dari pengujian pertama. Dengan demikian siswa dapat berinteraksi dengan chatbot sebagai media belajar bahasa pemrograman Java dan Chatbot dapat membantu pengajar dalam pemberian materi dan kuis. Dan juga hasil pengujian efektifitas melalui uji kualitas perangkat lunak ISO 9126 melibatkan beberapa aspek mendapat predikat sangat layak untuk diterapkan.
\end{abstract}

Kata kunci: google classroom, facebook messenger, chatbot, java, organizing exercise items.

\section{DESIGN OF CHATBOT LEARNING JAVA ON GOOGLE CLASSROOM AND FACEBOOK MESSENGER}

\begin{abstract}
Online class application has been applied in SMK Telkom Malang using Google Classroom platform on Object Oriented Programming subjects (OOP). Google Classroom on PBO subjects added Java learning chatbot material from the Oracle Academy Java Foundation using the Messenger Facebook platform. Both of these learning media can help teachers in providing materials to students such as basic Java programming materials and the presentation of items about the quiz. In the quiz model that is presented by this chatbot, the students get responses of different items in the quiz about the material that is displayed in accordance with the score of the difficulty level of the problems done by the students by the Organizing Exercise Items method. In the test results, chatbot is applied to the learning of 3 classes and creating a higher final exam results with an average difference of 0.60 points from the conventional learning group. In the learning results there is also an increase in the value of post test of 0.39 points from the first test. Thus the students can interact with chatbot as a learning medium Java programming language and Chatbot can help teachers in the provision of materials and quizzes. And result of effectiveness test through ISO 9126 software quality test some aspect gets predicate very feasible to applied.
\end{abstract}

Keywords: google classroom, facebook messenger, chatbot, java, organizing exercise items. 


\section{PENDAHULUAN}

Pembelajaran secara tatap muka di kelas kini dibantu dengan media kelas online atau media pembelajaran virtual yang memudahkan guru dan siswa untuk mendistribusikan materi, memberikan pengumuman dan instruksi, memberikan feedback, mengumpulkan hingga penilaian tugas ataupun kuis sehingga tanpa batasan waktu dan tempat (Kincaid, dkk. 2017). Di SMK Telkom Malang, kelas online yang digunakan dengan platform Google Classroom khususnya pada mata pelajaran Pemrograman Berorientasi Objek (PBO) atau dikenal juga Object Oriented Programming $(O O P)$ dengan materi didapat dari Oracle Acadeny Java Foundation. Dalam kelas online tersebut ada fitur lain yaitu guru dapat membentuk tim untuk berkolaborasi dalam pengaturan kelas tersebut. Namun dalam kelas online belum ada fitur chatting atau obrolan pribadi kepada tim guru, hanya berupa announcement yang bersifat pengumuman. Tim guru masih belum mampu melayani apabila beberapa siswa dalam satu waktu mengirim pernyataan ataupun pertanyaan secara pribadi kepada tim guru mengenai pembelajaran bahasa pemrograman Java

Beberapa channel platform obrolan atau chatting pribadi berbasis cloud seperti Facebook Messenger kini semakin marak dibantu bot atau chatbot menggunakan Artificial Intelligent dengan model sistem pakar (expert system) yang memproses bahasa alami atau Natural Language Processing $(N L P)$ dalam berbagai bidang ilmu (Athira, dkk. 2013; Alencar \& Netto. 2011). Chatbot pada bidang pendidikan dapat dimanfaatkan dalam pengembangan suatu media pembelajaran untuk siswa sebagai penyaji bahan materi dan kuis yang interaktif dan menarik dengan icon emosi (Morales, dkk. 2011), dengan konsep sistem modular dalam membagi blok pengetahuannya yaitu dalam membagi pilar konsep PBO (Rosa \& Shalahudin. 2013). Penyajian kuis melalui chatbot adalah perkembangan dari Question Answering (QA) system dengan NLP dan reasoning dibangun bertujuan dapat menjawab pertanyaan-pertanyaan yang terbatas (Hosanee \& Panchoo. 2015; Tanwar, dkk. 2014). Pada suatu bidang tertentu dengan berdasarkan pada sumber informasi yang terstruktur seperti basis data, sekarang dapat menampilkan beberapa jenis pertanyaan yang bersumber pada informasi dari sebuah koleksi teks tidak terstruktur (Madhu, dkk. 2017).

Platform Framewok pembangun chatbot AI berbasis cloud semakin marak pada saat ini tanpa kode ataupun digabungkan dengan bahasa pemrograman tertentu. Chatfuel sebagai framework pembangun chatbot atau bot builder telah digunakan oleh beberapa perusahaan tingkat dunia karena hanya memerlukan waktu respon yang singkat dalam menjawab banyak user sekaligus (Baiti \& Nugroho. 2013). Penyiapan algoritma dalam pembangunan chatbot yang dapat menyajikan kuis bahasa pemrograman Java ini mengembangkan algoritma Organizing Exercise Items (OEI) yang sebelumnya diterapkan pada aplikasi evaluasi belajar berbasis web di mata kuliah matematika kalkulus di Program Studi Jaringan Telekomunikasi Digital Politeknik Negeri Malang. Evaluasi dirancang untuk mengamati aktivitas siswa melalui pelacakan frekuensi siswa melakukan praktik serta catatan kegiatan siswa, termasuk item latihan yang telah selesai, waktu pelaksanaan praktik, dan skor yang dirahasiakan. (Widjajanti, dkk. 2015).

Berdasarkan penjelasan di atas, adanya chatbot yang dibangun dengan Chatfuel sebagai bot builder dengan Facebook Messenger sebagai platform channel chatting diharapkan dapat memberikan solusi kepada guru serta berkontribusi positif saat proses pembelajaran oleh siswa yang diintegrasikan pada kelas online Google Classroom tanpa batasan ruang, waktu dan jumlah siswa. Chatbot ini juga sebagai media pembelajaran yang menarik untuk menambah minat belajar siswa dibanding dengan aplikasi web form tanpa percakapan interaktif dalam memahami konsep hingga pengerjaan kuis bahasa pemrograman Java sesuai dengan tingkat score kompetensi dan pemahaman siswa dengan metode Organizing Exercise Items.

Penelitian tentang Artificial Intelligence (Chatbot) yang mengembangkan Chatbot AI pada platform Facebook Messenger. Chatbot yang dinamakan Locate_My_Destination menggunakan beberapa perangkat cloud platform service yaitu Microsoft Azure dan BoT Framework dengan integrasi Chatfuel dan Luis (Language Understanding Intelligent Service). Metode yang dikembangkan yaitu kombinasi antara Chatfuel dan MS LUIS Azure, kemudian digabung dengan API.ai sebagai chatbot builder sehingga mengubah bahasa manusia menjadi kata kunci dan kata kerja yang sesuai, kemudian mengirim ke Microsoft Azure Cloud untuk mencari jawaban. Kemudian Azure mengambil tindakan yaitu memanggil API atau memberi teks untuk membalas atau menghasilkan gambar (Shaikh \& Karala. 2017).

Penelitian tentang pengembangan aplikasi Facebook, bagaimana dapat dikembangkan, bagaimana dapat ditemukan, apa bot paling populer saat ini, dan lain-lain. Sebagai contoh penggunaan tujuan bisnis bot, diterapkan bot untuk bank bernama PseudoBank dan menunjukkan apa kelebihan dan kekurangan aplikasi bot untuk bisnis. Implementasi dilakukan dengan menggunakan alat bantu pengembangan bot gratis. Bot PseudoBank menawarkan kepada pengguna beberapa informasi bank umum: jenis pinjaman apa yang ditawarkan oleh bank, peluang yang ditawarkan bank untuk penghematan klien, bagaimana seseorang dapat membuka rekening bank, berapa nilai tukar mata uang saat ini, dsb. Selain itu, Satu komunikasi dengan klien, Facebook Messenger bot memiliki kemampuan 
untuk mengirim pesan broadcast atau siaran ke penggunanya. PseudoBank melalui antarmuka web administrasi Chatfuel dapat mengirim pesan siaran ke pengguna bank (Vukovic \& Dujlovic. 2016).

Penelitian tentang konsep chatbot dan platform awan yang berbeda untuk mengembangkan chatbot. Pengembang, aplikasi Facebook Messenger serta bisnis menjadi bekerja sama dan membangun lingkungan baru, karena penemuan chatbot. Chatbot dapat dikembangkan untuk tujuan seperti belanja, layanan pelanggan, pesanan makanan, update berita, reservasi dan banyak lagi. Semua platform awan yang dibahas dalam makalah ini memiliki fitur dan fungsi yang berbeda dan berdasarkan pada ini, kami telah mengembangkan beberapa chatbot yang efisien dan interaktif dan mendapatkan beberapa hasil. (Patil, dkk. 2017).

Penelitian tentang penentuan persyaratan alat perangkat lunak yang sesuai dengan kebutuhan siswa. Sebuah survei dilakukan untuk mengidentifikasi kesulitan peserta didik dan jenis dukungan yang mereka butuhkan saat berinteraksi dengan alat pendukung Object Oriented Programming (OOP). Yang terakhir ini juga mempertimbangkan fitur valid dari perangkat lunak pengajaran $O O P$ sebelumnya. Fitur tertentu, yang ada di dalam alat ini, juga melayani e-assessment yang memungkinkan pengguna mengetahui tingkat kemampuannya. Pembelajar pemula dapat memantau kemajuan mereka dan mengambil tindakan yang relevan. Dengan demikian, ini akan mendorong peserta didik pemula untuk terlibat dan termotivasi untuk belajar OOP dengan kecepatan mereka sendiri (Sweta \& Raghuwanshi. 2016).

Penelitian tentang fitur singkat Google Classroom telah dilakukan inovasi. Studi ini juga menyajikan beberapa bukti baru tentang potensi ruang kelas Google dalam mengajar. Akhirnya, beberapa saran mengenai harapan peserta didik juga diberikan kepada para guru dari berbagai disiplin ilmu yang ingin menggunakan Google Classroom (Iftakhar, 2016).

Penelitian tentang pembelajaran pemrograman saat ini juga harus dikembangkan dengan sebuah media pembelajaran baru dan interaktif bagi mahasiswa dengan mengintegrasikan berbagai faktor yang mempengaruhi permasalahan kurang memahami dasar pemrograman. Aplikasi learning by doing interaktif dapat mendukung pembelajaran bahasa pemrograman ini dibangun dengan pendekatan Web Framework. Aplikasi ini juga memanfaatkan fitur membagikan kode pemrograman yang dikembangkan oleh Trinket. (Sophan, 2018).

Dari beberapa penelitian terdahulu terdapat kesimpulan yang membedakan dan perbedaan tersebut dapat dilakukan penyatuan kerangka konsep rancangan chatbot pada penelitian saat ini yang sedang dilakukan. Beberapa hal perbedaan tersebut antara lain rancangan beberapa aplikasi chatbot yang terbangun dalam melayani pengguna telah menggunakan platform chatbot builder berbasis cloud di bidang bisnis namun belum mengarah pada materi pembelajaran di sekolah. Disamping itu juga meskipun ada penelitian tentang metode penyajian item soal dan rancangan aplikasi pembelajaran bahasa pemrograman bahkan berbasis OOP namun masih diterapkan hanya pada aplikasi website. Dan penelitian tentang Google Classroom yang digunakan pada instansi pendidikan sangat berpotensi untuk dilakukan inovasi pada proses pembelajaran di kelas.

\section{METODE PENELITIAN}

Penelitian yang dilakukan termasuk dalam bidang Rekayasa Software. Metode rekayasa sistem informasi yang disebut System Development Life Cycle (SDLC), langkah-langkah SDLC meliputi fase perencanaan, analisis, desain, implementasi dan pengujian. Pada tahapan perencanaan, dilakukan dengan identifikasi materi dan kuis yang akan dimasukkan dalam basis pengetahuan, kemudian cara memilih dan memilah untuk dapat disajikan kepada user sesuai tingkat kompetensi. Pada tahap analisis peneliti melakukan studi tentang chatbot builder yang dapat menerapkan dan mengembangkan metode, dan chatbot dapat dikoneksikan pada channel yang dapat dijangkau oleh semua siswa. Kemudian penelitian terhadap jenis soal dan penyajian materi dapat diterapkan pada chatbot dan dipahami oleh user, variabel, tipe data, dan alur. Pada tahap analisis juga mendata segala kebutuhan yang berhubungan dengan pembuatan dan pengembangan chatbot supaya dapat diterima baik oleh siswa.

Pada tahap perancangan desain berhubungan dengan chatbot builder dan konten yang menarik untuk ditampilkan sehingga interaksi obrolan dengan bot menarik. Baik alur dan tampilan dipertimbangkan bagi user setingkat siswa SMK pada umumnya supaya menarik dan tidak membosankan. Setelah itu dikomparasi kembali dengan perencanaan awal, jika tidak sesuai akan kembali mengamati perencanaan dapat dilakukan atau tidak. Jika proses sesuai dengan perencaan lanjut pada implementation yaitu pengembangan chatbot pada Chatfuel, penerapan metode Organizing Exercise Items dibangun dengan fitur-fitur chatbot builder. Hingga yang terakhir tahap pengujian chatbot dikoneksikan ke channel Facebook Messenger dan berinteraksi dengan siswa. Mengevaluasi kesesuian keluaran dengan masukan variable bebas dan terikat sesuai dengan perencaan. Diharapkan pada pengujian sudah tidak ada proses kembali ke perencaan karena sebelum penerapan metode sudah dapat diperbaiki, sehingga tahap testing hanya evaluasi antara masukan dan keluaran.

\section{PERANCANGAN CHATBOT PEMBELAJARAN JAVA}

Rancangan chatbot pembelajaran Java tampak dalam Gambar 1 dapat diawali dengan masukan teks dari user dalam hal ini siswa yang menggunakan akun 
Facebook Messenger. Link chatbot pada Facebook Messenger dipasang dalam material Google Classrom pada mata pelajaran Pemrograman Berorientasi Objek (PBO) di tingkat kelas XI RPL semester ganjil. Siswa dapat memasuki classroom tersebut dengan akun email sekolah yang sudah tergabung dalam classroom tersebut. Kemudian pada Chatfuel sebagai pembangun chatbot, admin sebelumnya telah menentukan respon chatbot. Teknik Forward Chaining pada proses penentuan respon menggunakan metode AI Rule Block dan Organizing Exercise Items. Metode AI Rule Block pada respon pada chatbot sesuai dengan NLP dan Sistem Pakar, dan penyajian item soal kuis ditentukan dengan metode Organizing Exercise Items yang membedakan item soal kepada siswa sebagai bentuk output pada Facebook Messenger.

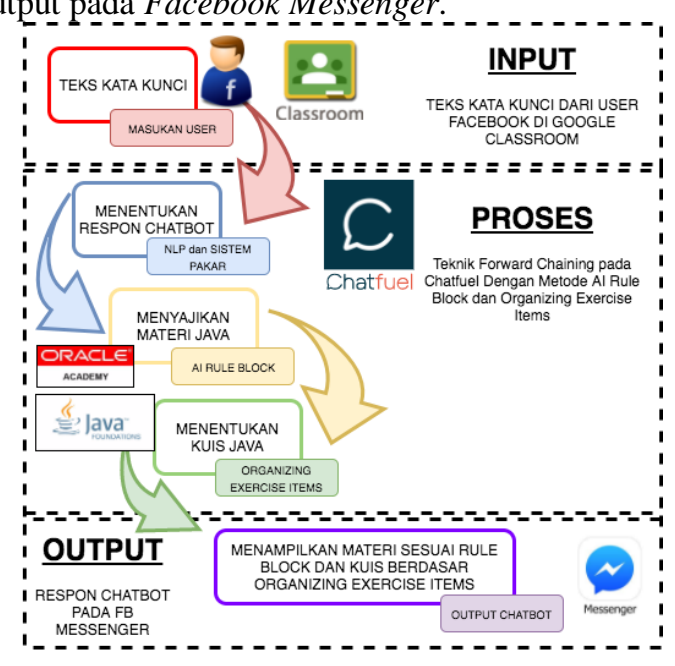

Gambar 1. Aliran proses chat yang dibangun

Tahapan perencanaan, dilakukan dengan identifikasi materi dan kuis yang akan dimasukkan dalam basis pengetahuan, kemudian cara memilih dan memilah untuk dapat disajikan kepada user sesuai tingkat kompetensi. Peneliti meneliti chatbot builder yang dapat menerapkan dan mengembang metode, dan chatbot dapat dikoneksikan pada channel yang dapat dijangkau oleh semua siswa. Kemudian penelitian terhadap jenis soal dan penyajian materi dapat diterapkan pada chatbot dan dipahami oleh user, variabel, tipe data, dan alur. Pada tahap analisis mendata segala kebutuhan yang berhubungan dengan pembuatan dan pengembangan chatbot supaya dapat diterima baik oleh siswa atau pengguna lain.

Pada tahap perancangan desain berhubungan dengan chatbot builder dan konten menarik yang bisa ditampilkan untuk interaksi obrolan menarik. Baik alur dan tampilan dipertimbangkan bagi user setingkat siswa SMK pada umumnya supaya menarik dan tidak membosankan. Setelah itu dikomparasi kembali dengan perencanaan awal, jika tidak sesuai akan kembali mengamati perencanaan dapat dilakukan atau tidak. Jika proses sesuai dengan perencaan lanjut pada implementation yaitu pengembangan chatbot pada Chatfuel, penerapan metode Organizing Exercise Items dibangun dengan fitur-fitur chatbot builder. Hingga yang terakhir tahap pengujian chatbot dikoneksikan ke channel Facebook Messenger dan berinteraksi dengan siswa. Mengevaluasi kesesuian keluaran dengan masukan variabel bebas dan terikat sesuai dengan perencanaan sesuai dalam Gambar 2.

Diharapkan pada pengujian sudah tidak ada proses kembali ke perencanaan karena sebelum penerapan metode sudah dapat diperbaiki, sehingga tahap testing hanya evaluasi antara masukan dan keluaran.

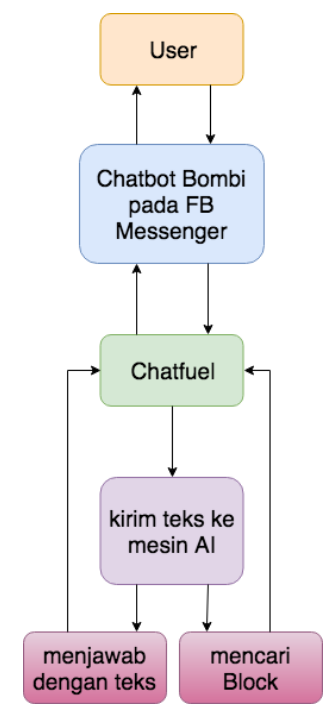

Gambar 2. Struktur percakapan user pada Chatfuel dan Facebook Messenger

\subsection{Perencanaan Sistem (Planning)}

Pada tahap ini ditetapkan spesifikasi chatbot yang dibangun berdasarkan kebutuhan metode yang diterapkan yaitu:

a) Sub Basis Pengetahuan

1. Sub basis pengetahuan tentang informasi akademis

2. Sub basis pengetahuan tentang materi dasar pemrograman Java dan konsep OOP. Sub basis pengetahuan dalam bimbingan belajar dapat memberikan keluaran berupa materi $P D F$ sesuai section yaitu: Java Software Development.

3. Sub basis pengetahuan dalam chatbot berfungsi sebagai sumber informasi yang menjadi respon atau keluaran kepada user ketika diberikan masukan kata kunci. Spesifikasi sub basis pengetahuan chatbot pada penelitian ini adalah kuis yang didapat dari ilearning.oracle.com dan sudah dimasukkan pada block chatfuel sesuai group section Java Foundation.

b) Sub sistem model

Sub sistem model dalam sisem ini berfungsi untuk mengimplementasikan sistem menggunakan 
metode Organizing Exercise Items, yaitu (a) nama bot; (b) group block; (c) set up AI; (d) exercise; (e) section; (f) level; dan (g) score.

c) Sub sistem end user interface (UI)

Sub sistem $U I$ berfungsi untuk visualisasi dari chatbot, sehingga pengguna bisa melakukan interaksi dengan sistem.

\subsection{Desain}

\section{A. Use Case}

Diagram use case adalah gambar untuk memodelkan kelakuan (behavior) sistem informasi yang dibuat. Use case diagram mendeskripsikan sebuah hubungan antara satu atau lebih aktor dengan sistem informasi yang dibuat. Pada intinya, use case digunakan untuk mengetahui fungsi apa saja yang ada di dalam sebuah sistem informasi dan siapa saja yang berhak menggunakan fungsi-fungsi itu (Rosa, 2013). Desain Unified Modelling Language dibuat mengacu pada sisi analisis kebutuhan agar aplikasi dapat berjalan sesuai dengan fungsi-fungsi yang diperlukan. Use case bisa disebut menggambarkan apa yang dilakukan sistem dapat dilihat dari sisi pengguna.

Sistem yang dibangun yaitu berupa aplikasi chatbot pembelajaran bahasa pemrograman Java dengan metode organizing exercise items. Berdasarkan analisis kebutuhan, di dalam aplikasi ini yang berperan pertama sebagai aktor adalah admin. Use case user yaitu Login, Dashboard, Set Up AI, dan Build serta fungsi-fungsi pendukung yang berkaitan dengan fungsi utama. Tampak dalam Gambar 3 Use case admin yaitu Login, Informasi Sekolah, Belajar Java dan Kuis Java Foundation serta fungsi pendukungnya.

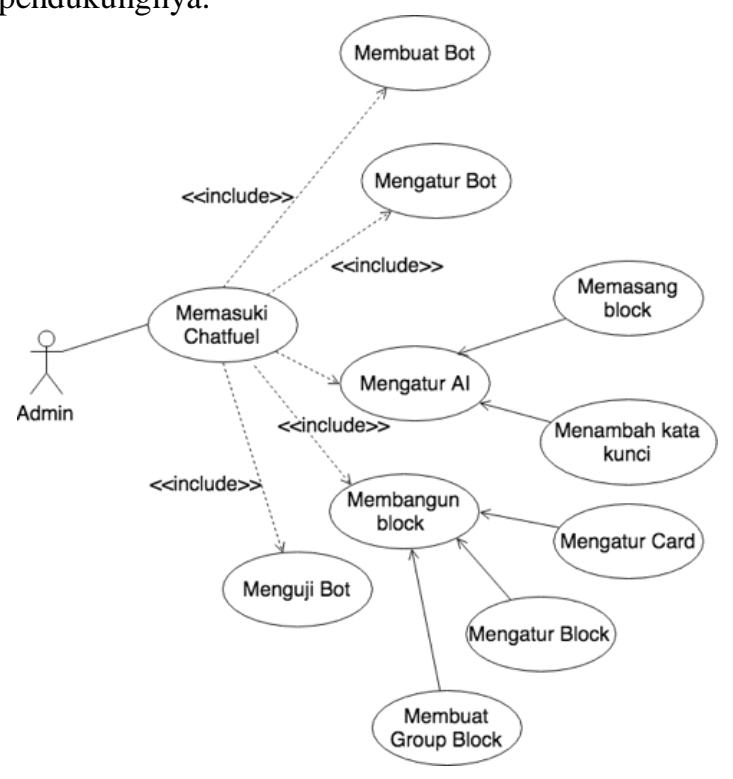

Gambar 3. Use case diagram admin

Aktor berikutnya adalah guru, siswa dan pengguna lain. Pada aktor guru dan siswa dalam hal ini sudah tergabung dalam kelas online. Use case aktor dapat dilihat pada Gambar 4. Aktor guru membuat seperangkat tes untuk menentukan kelompok sehingga pada kelas terdapat dua kelompok yang berinteraksi dengan chatbot dan kelompok yang mendapat materi oleh Guru sebagai uji coba. Aktor siswa pertama kali use case yang dilakukan adalah login Classroom dan Facebook untuk Messenger, kemudian dapat mengetikkan kata kunci untuk dapat melanjutkan interaksi penggalian informasi tentang Sekolah, materi Java dan pengerjaan kuis. Aktor pengguna lain dapat langsung berinteraksi dengan chatbot dengan akun Facebook tanpa harus ke Classroom.

Tabel 1. Use case scenario admin

\begin{tabular}{|l|l|}
\hline Use Case Admin Memasuki Chatfuel \\
\hline Tujuan & $\begin{array}{l}\text { Mengijinkan admin menguji } \\
\text { chatbot }\end{array}$ \\
\hline Aktor & Admin \\
\hline Kondisi Awal & Login tervalidasi dan valid \\
\hline Skenario Utama & $\begin{array}{l}\text { 1. Admin mengatur Bot } \\
\text { 2. Admin menguji Bot }\end{array}$ \\
\hline $\begin{array}{l}\text { Skenario } \\
\text { Alternatif }\end{array}$ & $\begin{array}{l}\text { 1. Admin membuat bot } \\
\text { 2.Admin mengatur AI } \\
\text { 3. Admin membangun block }\end{array}$ \\
\hline Kondisi Akhir & $\begin{array}{l}\text { Sistem menampilkan jendela } \\
\text { menguji Bot }\end{array}$ \\
\hline
\end{tabular}

Use Case skenario pada Admin terlihat di Table 1 dimana use case saat memasuki Chatfuel, admin setelah login dan valid akan case utama adalah mendapatkan bot yang telah dibuat untuk diatur dan diuji pada channel Messenger. Alternatif case admin juga dapat membuat bot lain atau mengatur AI dan membangun block pada bot yang sudah dibuat sebelumnya.

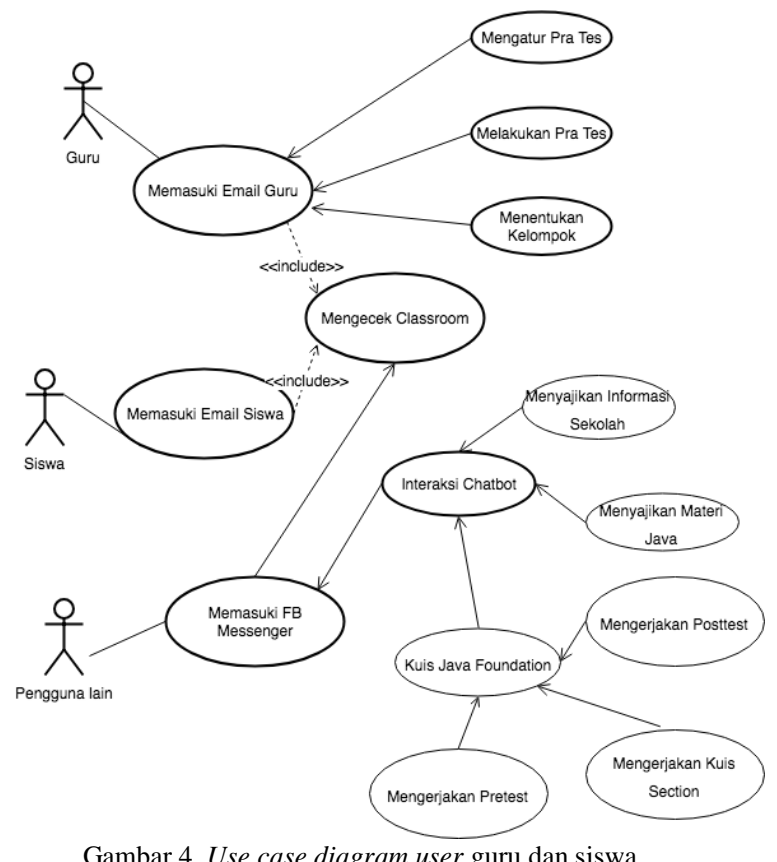

Gambar 4. Use case diagram user guru dan siswa

\section{B. Sub sistem pengetahuan}


Pembuatan group block (kumpulan beberapa block) yang terbentuk untuk mengimplementasikan penyajian soal kuis dengan metode Organizing Exercise Items.

Item kuis ditampung pada variabel diberi nama ExLxSx yang identik dengan posisi user menjawab kuis. Untuk detailnya yaitu:

$$
\begin{aligned}
& \text { Ex }=\text { Exercise } x \\
& \text { Lx }=\text { Level } x \\
& \text { Sx }=\text { Section } \mathrm{x} \\
& \mathrm{x}=\text { angka posisi }
\end{aligned}
$$

\begin{tabular}{|r|r|r|}
\hline E1L1S2A & E1L2S2A & E1L3S2A \\
E2L1S2A & E2L2S2A & E2L3S2A \\
E3L1S2A & E3L2S2A & E3L3S2A \\
E4L1S2A & E4L2S2A & E4L3S2A \\
E5L1S2A & E5L2S2A & E5L3S2A \\
nextL1S2A & nextL2S2A & nextL3S2A \\
endL1S2A & endL2S2A & endL3S2A \\
\hline scoreL1S2A =0 & scoreL2S2A =0 & scoreL3S2A $=0$ \\
\hline
\end{tabular}

Gambar 5. Group block dari Chatfuel bot builder

Contoh pada block endL1S2A dalam Gambar 5 terlihat block akhir yang menentukan posisi level dan section berikutnya, dari akumulasi score di section sebelumnya.

Sedangkan score diperoleh dari posisi awal ditambahkan hingga kuis terakhir pada section sehingga dapat mengarahkan ke kuis berikutnya pada posisi section dan level tertentu seperti tampak dalam Gambar 6. Pada 1 block juga terdapat 1 soal pada Card text sebagai penyimpan soal dan respon pilihan yang dapat dipilih dengan cara diklik seperti tombol dan memberikan respon sebagai masukan kembali chatbot.

Pada block Card Chatfuel terdapat JSON API yang dapat digunakan untuk mengirimkan data masukan percakapan dari user ke penyimpanan pihak ketiga yaitu Airtable. Card JSON API tampak dalam Gambar 7 digunakan untuk mengirimkan data yaitu dengan type POST ke URL Runkit menggunakan Node.js dan NPM. Pada Card JSON API akan mengirimkan beberapa user attributes yang diperlukan diantaranya firstname, lastname, score pretest, score tiap Level Section dan score post test untuk dapat dianalisa setelah terkumpul dari beberapa user.

\section{Sistem Blok}

Secara sederhana desain sistem blok merupakan orientasi yang membagi sistem menjadi beberapa bagian kecil (modul) yang secara mandiri dibuat dan kemudian digunakan dalam sistem yang berbeda untuk mengarahkan beberapa fungsi. Ide pokok dari desain modular yaitu untuk dapat mengembangkan serangkaian komponen produk dasar yang dapat dirakit menjadi sejumlah besar produk dalam bentuk Card yang tersusun dalam hal ini topik pembelajaran dan soal kuis yang disajikan sebagai respon atau jawaban dari chatbot seperti tampak dalam Gambar 8 dibawah ini.

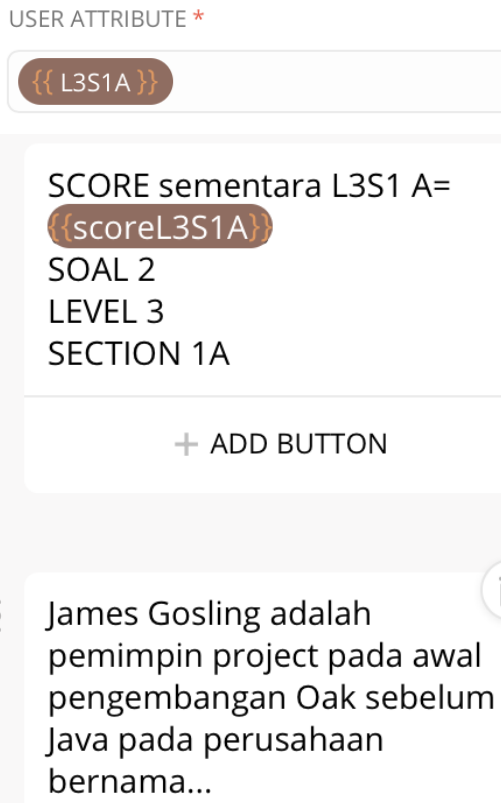

SCORE sementara L3S1 A=

\section{\{scoreL3S1A\}}

SOAL 2

LEVEL 3

SECTION $1 \mathrm{~A}$

+ ADD BUTTON

James Gosling adalah pemimpin project pada awal pengembangan Oak sebelum Java pada perusahaan bernama...
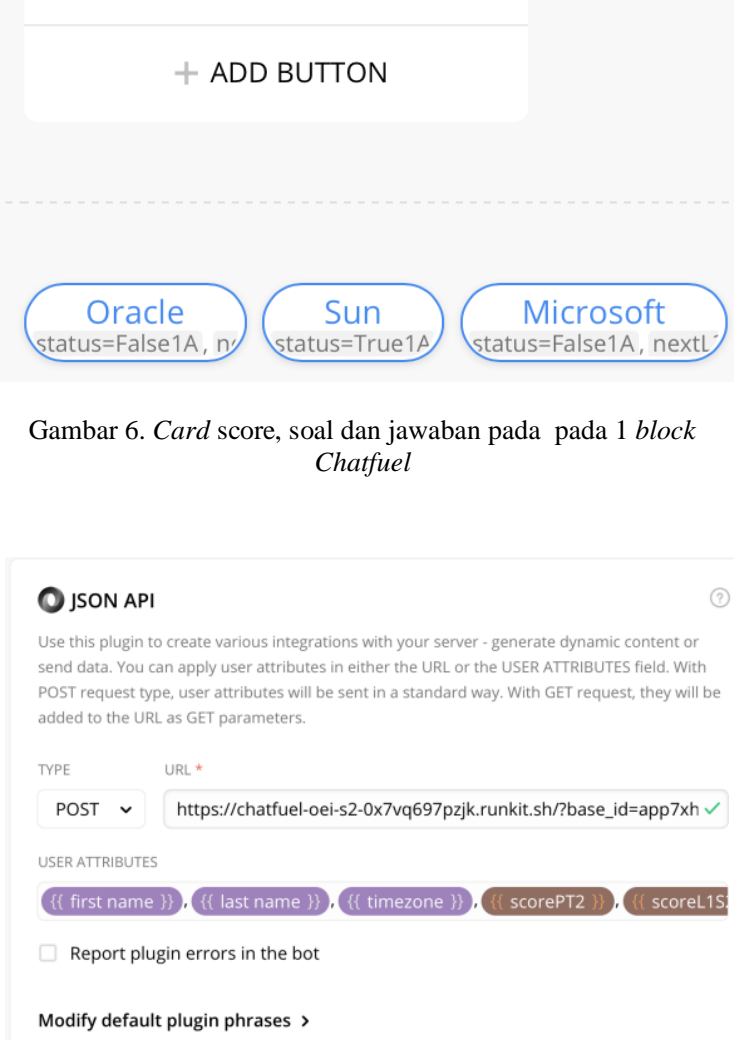

Gambar 7. Card JSON API 


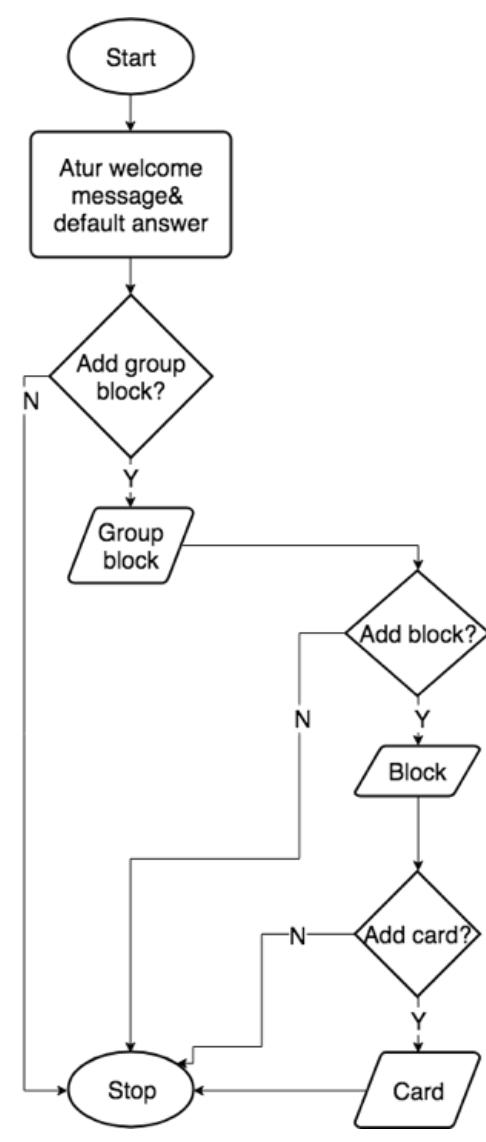

Gambar 8. Alur rancangan respon bot

\section{Sub sistem user interface}

Tampilan user interface atau antar muka untuk pengguna dengan chatbot berupa jendela chat yang dibuat dengan menggunakan platform channel Messenger pada Facebook FanPage dengan Nama Bombi (Bocah Moklet Bionik) seperti tampak dalam Gambar 9.

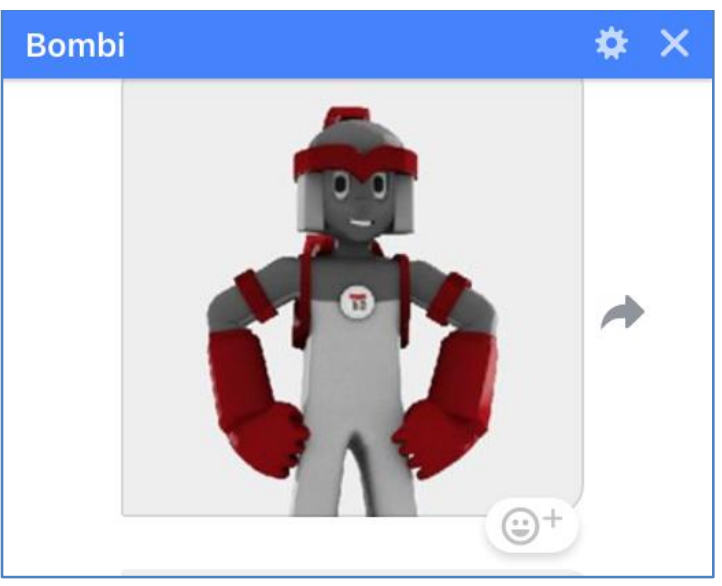

Gambar 9. Jendela mini chatbot pada Facebook

\section{HASIL DAN PEMBAHASAN}

\subsection{Analisis kebutuhan perangkat lunak}

Untuk membangun chatbot dibutuhkan beberapa spesifikasi kebutuhan aplikasi pendukung yang responsive sesuai perkembangan teknologi yang ada. Facebook sebagai pilihan platform chatbot karena sebagian besar siswa menggunakan facebook untuk media sosial dan didukung aplikasi pengirimana pesan yang berkembang untuk chatbot yaitu Messenger, bahkan juga akhir-akhir ini sudah mempunyai alamat URL terpisah dengan Facebook. Chatfuel juga menjadi pilihan sebagai bot builder karena tanpa pengkodean yang relatif mudah dan cepat dalam pembangunan maupun implementasi interaksi saat chatbot dikoneksikan ke aplikasi chat. Chatfuel mempunyai beberapa fitur block yang mendukung logika program IF-THEN sehingga dapat menerapkan metode Organizing Exercise Items seperti tampak dalam Gambar 10.

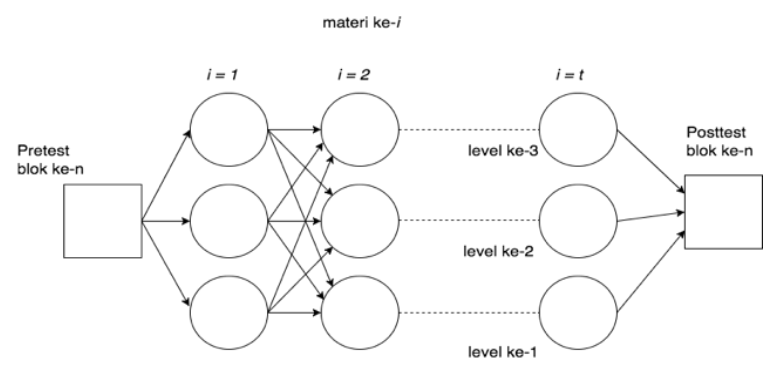

Gambar 10. Alur dari metode Organization Exercise Items

\subsection{Analisis pemodelan perangkat lunak}

Pada tahap hasil ini membawa desain menuju coding atau build the block and logic dengan menggunakan integrasi aplikasi Chatfuel dan Facebook Messenger. Wujud dari hasil implementasi ini adalah sebuah chatbot yang siap diuji dan digunakan dari penggunaan perangkat keras dan perangkat lunak sesuai analisis spesifikasi kebutuhan sebelumnya.

Konsep algoritma dari pembuatan bot hingga percakapan user dan chatbot dapat dilihat pada flowchart dalam Gambar 11. Pada Chatfuel disediakan pembuatan bot dengan tipe kosong atau dengan template, kemudian diintegrasikan pada Facebook Messenger yang terdapat di Facebook Page. Setelah terhubung, pada Chatfuel bot pengaturan AI yang dapat dilakukan yaitu Set Up AI, Group dan penambahan Rule. Kemudian tambahkan skenario percakapan dengan menambah user says yaitu kata kunci dan bot replies yaitu respon. Respon bot dapat berupa teks atau block yang sudah dibuat sebelumnya. Proses penentuan respon dapat dilakukan sesuai kebutuhan dan kemudian mencobanya pada Facebook Messenger. 


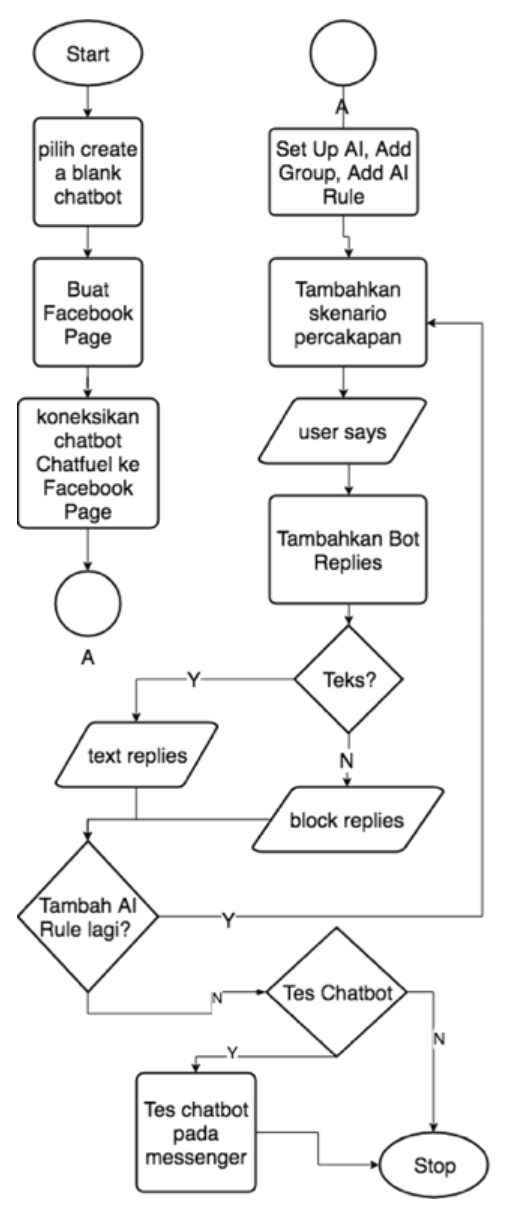

Gambar 11. Flowchart pembangunan chatbot pada Chatfuel

\subsection{Pengujian}

Pada penerapan chatbot pembelajaran, skenario awal adalah dengan memberikan masukan text sapaan, kemudian pengguna dapat membalas sapaan tersebut. Kemudian pengguna melanjutkan untuk memasukkan text kata kunci yang nantinya mendapat respon. Pengguna dapat memasukkan kata kunci tentang informasi sekolah, materi belajar tentang pemrograman Java dan pengerjaan kuis.

User menekan tombol mulai atau mengetikkan pada kolom masukan jendela chat kemudian beberapa detik akan muncul salam dan perkenalan dari chatbot. Chatbot kemudian menawarkan beberapa informasi berkaitan dengan sekolah dan mata pelajaran. Jika user langsung memilih atau mengetikkan kata kunci yang memuat konten pembelajaran dan kuis, maka chatbot menawarkan untuk menyajikan konten pembelajaran maupun kuis.

Tampak dalam Gambar 12 tampilan respon awal ketika chatbot dikunjungi atau pengguna memberikan kalimat sapaan. Dalam Gambar 13 pengujian respon chatbot ketika pengguna memasukkan kata kunci informasi sekolah tentang jadwal pelajaran, dalam Gambar 14 hasil respon chatbot dalam pemberian materi pemrograman Java.

Berdasarkan hasil pengujian, chatbot dapat memberikan respon sesuai dengan apa yang dimasukkan oleh pengguna. Berikut adalah tabel pengujian respon dan beberapa gambar tampilan respon pada chatbot:

Pengujian Perangkat Lunak dilakukan dengan verifikasi dan validasi. Verifikasi merujuk pada sekumpulan tugas yang memastikan bahwa perangkat lunak benar menerapkan fungsi yang ditentukan. Validasi merujuk ke sekumpulan tugas yang berbeda yang memastikan bahwa perangkat lunak yang dibangun dapat dilacak berdasar persyaratan pelanggan (Pressman, 2015). Pengujian Efektifitas penggunaan chatbot dilakukan dengan mengukur kualitas penggunaan chatbot dengan mempertimbangkan aspek pengujian pada ISO 9126 seperti dalam Tabel 2.

\begin{tabular}{|c|c|c|c|}
\hline No & Pengujian & Alat & Hasil pengujian \\
\hline 1 & Functionality & kuesioner & $\begin{array}{l}\text { Ahli Media 85,5\%, } \\
\text { Ahli RPL 96\% dan } \\
\text { ahli materi 92,4\% }\end{array}$ \\
\hline 3 & Usability & $\begin{array}{l}\text { kuesioner } \\
S U P R-Q\end{array}$ & $82,6 \%$ Sangat Baik \\
\hline 2 & Reliability & $\begin{array}{l}\text { Analyze } \\
\text { Chatfuel }\end{array}$ & $\begin{array}{l}851 \text { dari } 873 \\
\text { pengguna mendapat } \\
\text { respon Default } \\
\text { Answer }\end{array}$ \\
\hline 4 & Efficiency & $\begin{array}{l}\text { grade \& } \\
\text { response } \\
\text { time }\end{array}$ & $\begin{array}{l}84 \text { grade A 4,03 } \\
\text { deitk }\end{array}$ \\
\hline 5 & Maintability & $\begin{array}{l}\text { blackbox } \\
\text { testing }\end{array}$ & $\begin{array}{l}\text { Correct Faults, } \\
\text { Consistency, } \\
\text { Simplicity }\end{array}$ \\
\hline 6 & Portability & web browser & $100 \%$ sukses \\
\hline
\end{tabular}

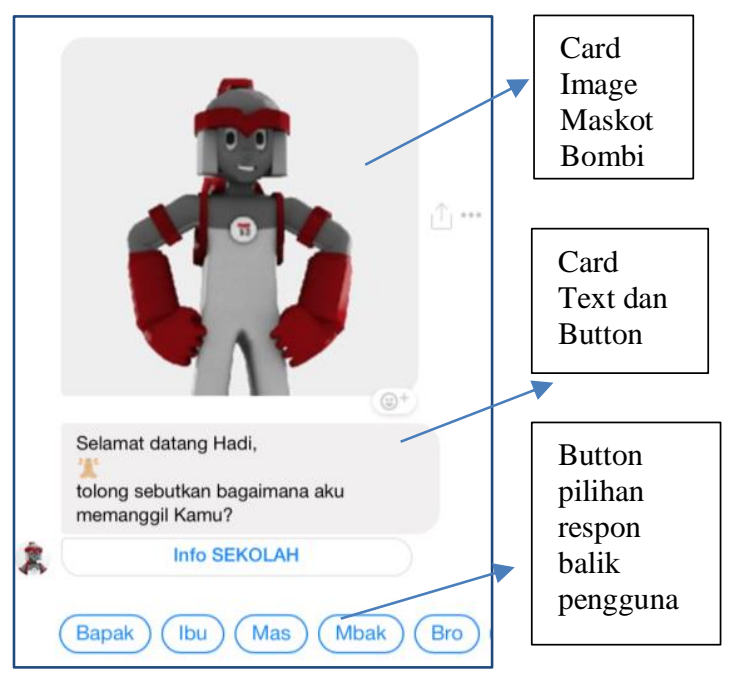

Gambar 12. respon awal sapaan pada chatbot 


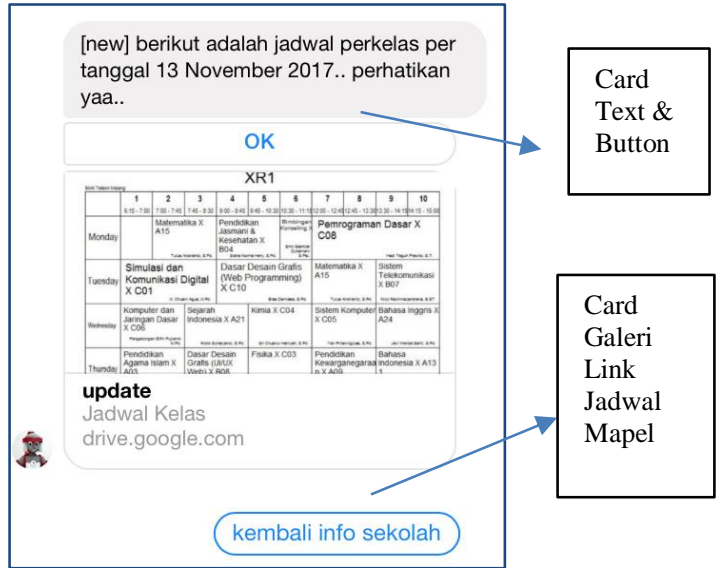

Gambar 13. Respon informasi sekolah pada chatbot

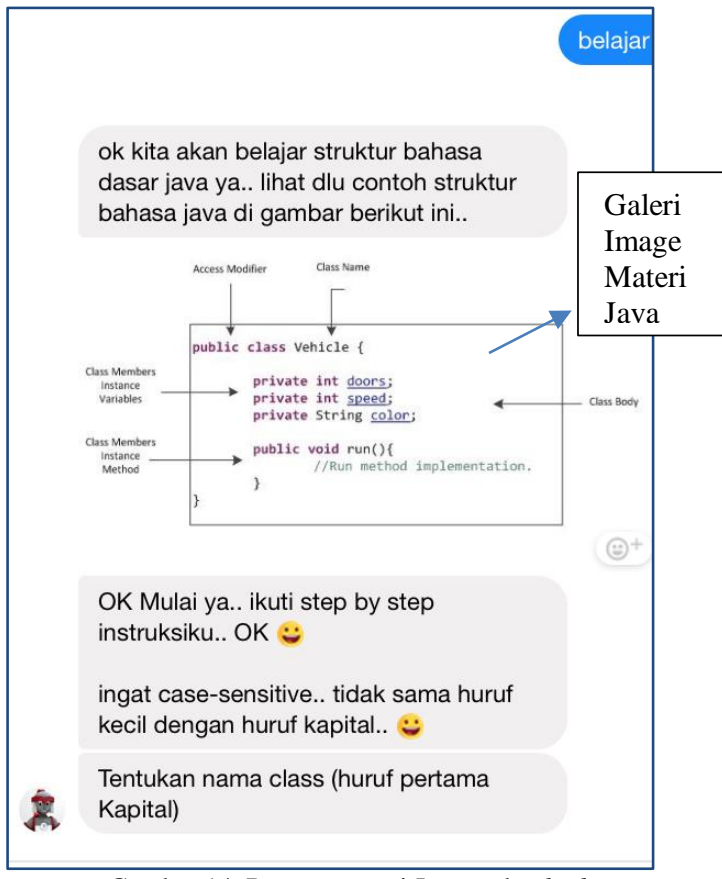

Gambar 14. Respon materi Java pada chatbot

Pada Tabel 3 tampak contoh soal disajikan 3 section yaitu $2 \mathrm{~A}$ yang masing-masing terdapat soal dengan 3 Level, yaitu:

$$
\begin{aligned}
& \text { L1 }=\text { Mudah } \\
& \text { L2 }=\text { Sedang } \\
& \text { L3 }=\text { Sulit }
\end{aligned}
$$

Tabel 3. Materi Section dan Soal per Level pada Kuis

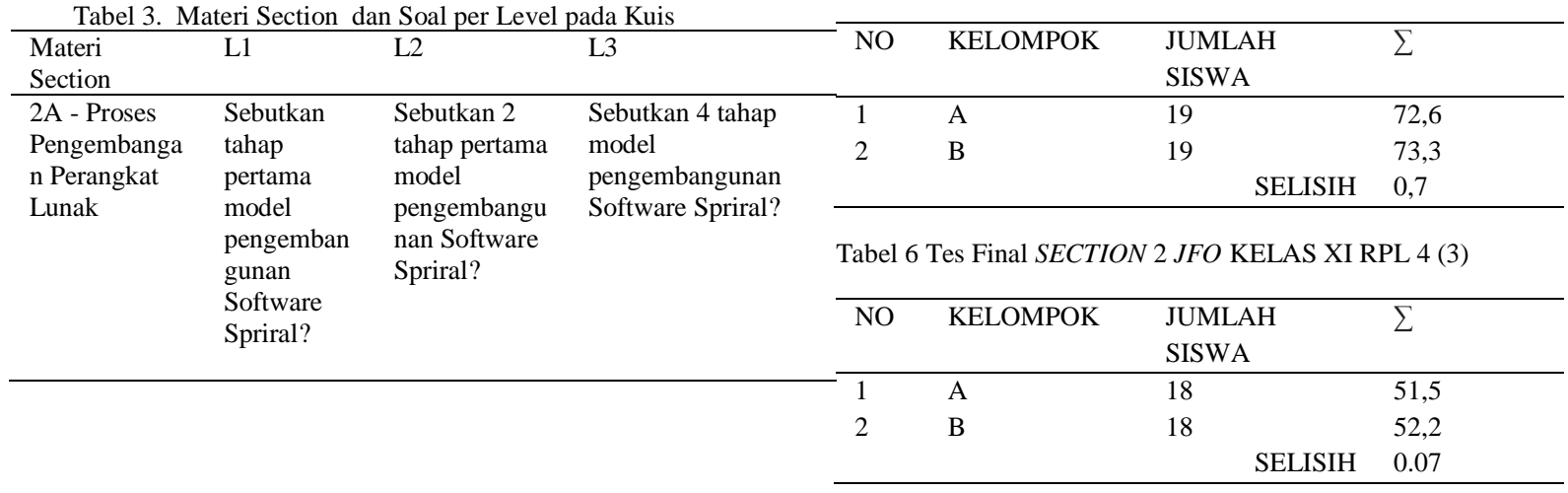

Pada Gambar 15 alur penyajian soal akan diterapkan dan disebutkan alur skenario pada ujicoba perbandingan kelas konvensional dan menggunakan chatbot yang kemudian pengguna mengerjakan kuis dengan metode $O E I$ dengan alur sebagai berikut:

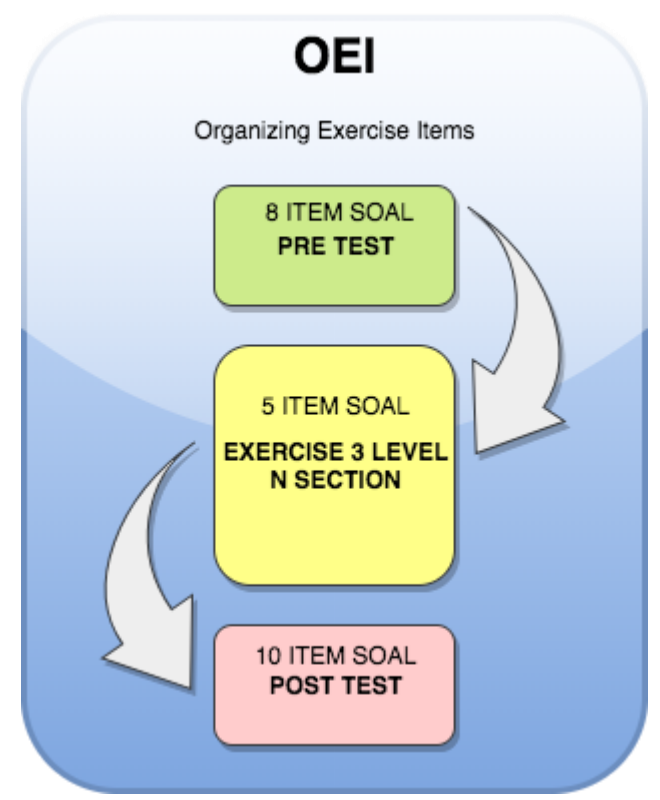

Gambar 15. Diagram alur penyajian soal dengan metode OEI

Alur ujicoba kepada siswa yaitu:

1. Menentukan 3 kelas yaitu XI RPL 6-5-4,

2. Membagi 2 kelompok per kelas dengan pra tes

3. Pada kelompok A diberikan materi klasikal

4. Pada kelompok B, materi dengan interaksi chat

5. Kelompok A dengan bimbingan guru

6. Kelompok B mengerjakan item soal dengan metode OEI = pretest - quis 3 section - post test

7. Record hasil kelompok B

8. Kelompok B mengulangi sebagai rekaman latihan kedua sehingga ada peningkatan belajar

\begin{tabular}{|c|c|c|c|}
\hline $\mathrm{NO}$ & KELOMPOK & $\begin{array}{l}\text { JUMLAH } \\
\text { SISWA }\end{array}$ & $\sum$ \\
\hline 1 & A & 17 & 64,3 \\
\hline \multirow[t]{2}{*}{2} & B & 17 & 64,7 \\
\hline & & SELISIH & 0,4 \\
\hline
\end{tabular}

9. Kelompok A dan B mengerjakan final soal

Tabel 4. Tes Final SECTION 2 JFO KELAS XI RPL 6 (1)

Tabel 5. Tes Final SECTION 2 JFO KELAS XI RPL 5 (2) 
Berdasarkan ujicoba siswa mengerjakan Tes Final yang dilakukan 2 kelompok pada 3 kelas seperti tampak dalam Tabel 4, 5 dan 6 ada selisih lebih besar kelompok yang menjalani pembelajaran melalui media chatbot Bombi. Pada kelas pertama ada selisih 0,4 poin, kelas kedua 0,7 poin dan kelas ketiga 0,7 poin dari kelompok pembelajaran konvensional. Dari hal tersebut dinyatakan chatbot dapat membantu peran guru dalam menyajikan materi dan item soal sesuai kemampuan siswa berdasar skor.

Pada ujicoba peningkatan hasil belajar dapat diketahui pada grafik dalam Gambar 20 dan 21 terdapat kenaikan sebesar 0,39 dari hasil pengerjaan siswa pada kelas pertama. Ini menunjukkan ada ketertarikan siswa dalam mempelajari materi pemrogramana Java menggunakan chatbot.

\section{KESIMPULAN}

Berdasarkan rangkaian pengujian dan penilaian yang telah dilakukan maka dapat disimpulkan bahwa Rancangan Chatbot Pembelajaran Java Foundation ini dapat memberikan respon percakapan dengan siswa baik pada pemberian awal percakapan hingga pemberian materi pemrograman Java dan kuis dari topik materi Java Software Development. Penerapan blok pengetahuan untuk menyajikan soal berbeda tingkat pada chatbot dapat dibangun dengan Chatfuel sebagai bot builder. Platform Channel Chatbot dapat dipasang pada Facebook FanPage Messenger dengan pertimbangan semua siswa mempunyai akun sebagai penyaji materi dan penyajian item kuis dengan metode OEI sesuai tingkat pemahaman siswa dapat membantu peran pengajar.

Penelitian lebih lanjut disarankan penggunaan kalimat sebagai data gabungan kata kunci dan respon yang lebih bervariasi sehingga dapat digunakan dengan banyak macam keluaran respon chatbot. Dengan menggunakan Machine Learning, teks masukan dapat diolah juga dapat menjadi respon balik dari chatbot. Penggunaan bobot nilai pada setiap jawaban siswa, dan menggabungkan metode yang ada dengan beberapa metode yang lain untuk menambahkan sinonim kata dan respon jawaban dengan text maupun icon emosional pada sistem databasenya sehingga didapat hasil yang lebih baik dan menarik. Penerapan chatbot dapat dilakukan pada mata pelajaran selain PBO dengan konten data respon sesuai materi saat membangun bot pada Chatfuel.

\section{DAFTAR PUSTAKA}

ALENCAR, M. \& NETTO, J.M., 2011. Improving Cooperation in Virtual Learning Environments Using Multi-Agent Systems and AIML. IEEE.

A.S., ROSA \& SHALAHUDIN, M., 2013. Rekayasa Perangkat Lunak Terstruktur Dan Berorientasi Objek. Bandung: Informatika.

ATHIRA P. M., SREEJA M. \& P. C. REGHURAJ., 2013. Architecture of an Ontology-Based Domain-Specific Natural Language
Question Answering System. International Journal of Web \& Semantic Technology (IJWesT). Vol.4: 4.

BAITI, Z.N. \& NUGROHO, F., 2013. Aplikasi Chatbot MI3 untuk Informasi Jurusan Teknik Informatika Berbasis Sistem Pakar Menggunakan Metode Forward Chaining. Malang: UIN Maulana Malik Ibrahim Malang.

HOSANEE, Y. \& PANCHOO, S., 2015. An Enhanced Software Tool to Aid Novices in Learning Object Oriented. IEEE.

IFTAKHAR, S., 2016. Google Classroom: What Works and How?. Journal of Education and Social Sciences, Vol. 3.

KINCAID, R. \& POLLOCK, G., 2017. Nicky: Toward A Virtual Assistant for Test and Measurement Instrument Recommendations. IEEE.

MADHU, D., JAIN, N., SEBASTIAN, E., SHAJI, S. \& AJAYAKUMAR, A., 2017. A Novel Approach for Medical Assistance Using Trained Chatbot. IEEE.

MORALES, M.L., GONZALES, J.J. \& JUAREZ, R.F., 2012. Emotional Dialogue in a Virtual Tutor for Educational Software. Research in Computing Science 56: 19-27.

PATIL, A., MARIMUTHU, K, RAO, N. \& NIRANCHANA, R., 2017. Comparative study of cloud platforms to develop a Chatbot. International Journal of Engineering \& Technology. 6 (3): 57-61.

PRESSMAN, R.S. \& MAXIM, B.R., 2015. Software Engineering: A Practitioner's Approach 8th Edition. NY: McGraw-Hill.

SHAIKH, A.M.A. \& KARALA, Y., 2017. Artificial Intelligence(Chat BoT's). International Journal of Scientific \& Engineering Research. Volume 8: Issue 2.

SOPHAN, M.K. \& Kurniawati, A., 2018. Perancangan Aplikasi Learning by Doing Interaktif untuk Mendukung Pembelajaran Bahasa Pemrograman. JTIIK.

SWETA P. LENDE \& DR.M.M. RAGHUWANSHI, 2016. Question Answering System on Education Acts Using NLP Techniques. IEEE.

TANWAR, P., PRASAD, T.V. \& DATTA, K., 2014. An Effective Reasoning Algorithm for Question Answering System. Ijacsa.

VUKOVIC, D.R. \& DUJLOVIC, I.M., 2016. Facebook Messenger Bots and Their Application for Business. IEEE.

WIDJAJANTI., K., SAROSA, M. \& KUSUMAWARDHANI, M., 2015. Organizing Exercise Items in Mathematics Learning. IJSR. 